\title{
MENGENAL UNDUR-UNDUR LAUT (CRUSTACEA: DECAPODA: HIPPIDAE) DAN MANFAATNYA BAGI KEHIDUPAN
}

\author{
Oleh \\ Rianta Pratiwi ${ }^{1}$
}

\begin{abstract}
GET CLOSER TO KNOW THE SEA MOLE CRAB (CRUSTACEA: DECAPODA: HIPPIDAE) AND THE BENEFITS FOR LIFE. The mole crab or also known as yutuk is an animal belonging to the group of crustaceans. The crab has a small body size and live immersed in the open beach sand in the tropics and sub-tropics. In Indonesia, many are found along the beaches around Yogjakarta, Central Java. One of the most common of species is Emerita emertus, Hippa adactyla and Hippa ovalis. It is highly hunted by the locals as the crab has high economic value, especially for source of nutrious food. Ecologically the crab is an important component in the food chain, in which the crab acts as an initial consumer in trophic level. Continuous and large-scale harvesting can disrupt the stability of the population in nature, therefore knowledgebased management is required to sustain the balanced population
\end{abstract}

\section{PENDAHULUAN}

Masyarakat di Indonesia banyak yang belum mengenal hewan undurundur (mole crab) yang tergolong hewan komersial dari kelompok crustacea, umumnya yang mereka kenal hanyalah lobster, udang, kepiting, teritip dan kelomang. Hewan yang menghuni pantai berpasir di daerah intertidal merupakan komponen penting dari komunitas makrobentos di pantai berpasir terbuka, baik di daerah tropis maupun di negaranegara yang memiliki empat musim (Dugan dalam Mashar \& Wardiatno, 2013a). Salah satu jenis undur-undur laut yang banyak dijumpai di Indonesia adalah jenis Emerita emeritus, Hippa adactyla, Hippa ovalis dan Blepharipoda occidentalis (Gambar 1 \& 2) (Mashar
\& Wardiatno, 2013 a \& b). Undurundur laut jenis E. emiretus dikenal dengan nama lokal "yutuk jambe" dan $H$. adactyla dikenal dengan nama lokal "yutuk batok".

Secara ekonomi, undur-undur laut menjadi sumber penghasilan (mata pencaharian) bagi beberapa nelayan di daerah pesisir Indonesia (Jawa Tengah), baik untuk konsumsi keluarga ataupun dijual sebagai makanan (jajanan) berupa kudapan dan laut pauk (karena mempunyai kandungan gizi yang cukup tinggi, terutama mengandung protein dan omega-6). Selain dijual sebagai makanan, hewan ini juga digunakan sebagai umpan pancing dan pakan hewan ternak seperti itik (karena telur itik yang dihasilkan akan mengandung omega-3)

\footnotetext{
$\overline{1)}$ Pusat Penelitian Oseanografi-LIPI
} 
(Hartono et al., 2010). Pemanfaatan sebagai bahan makanan tambahan sudah lama dilakukan oleh masyarakat nelayan di wilayah pesisir kabupaten Kebumen dan daerah-daerah lain di sekitar pantai di Jawa Tengah. Namun demikian, secara ekologi undur-undur laut merupakan sumberdaya penting dalam siklus rantai makanan yang pada trofik level merupakan konsumen tingkat awal di daerah pantai berpasir (Hurband \& Dugan dalam Megawati, 2012).

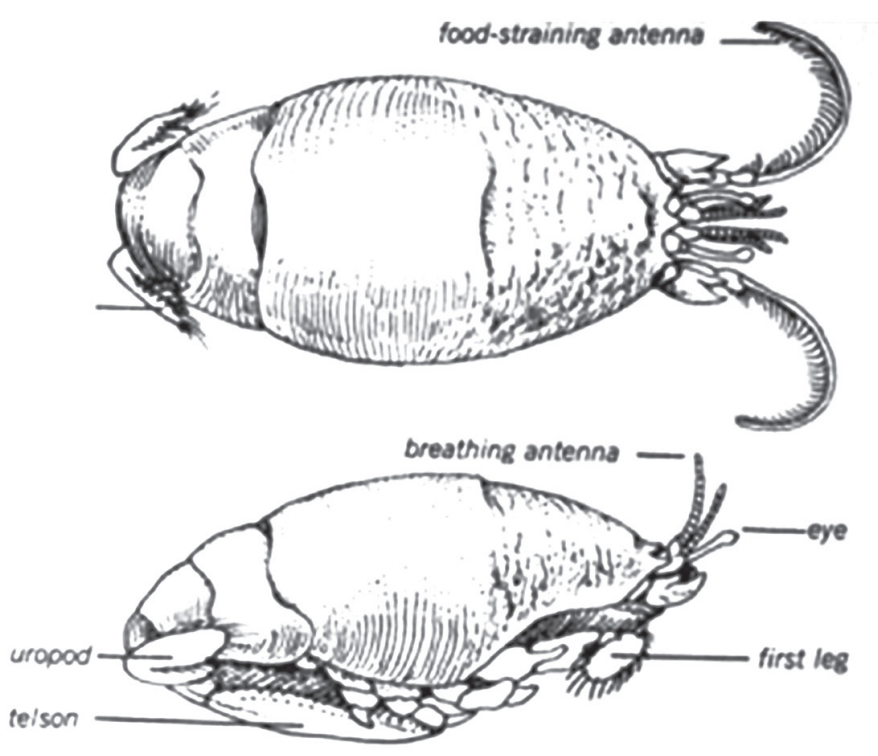

Gambar 1. Emerita sp. (Megawati, 2012)

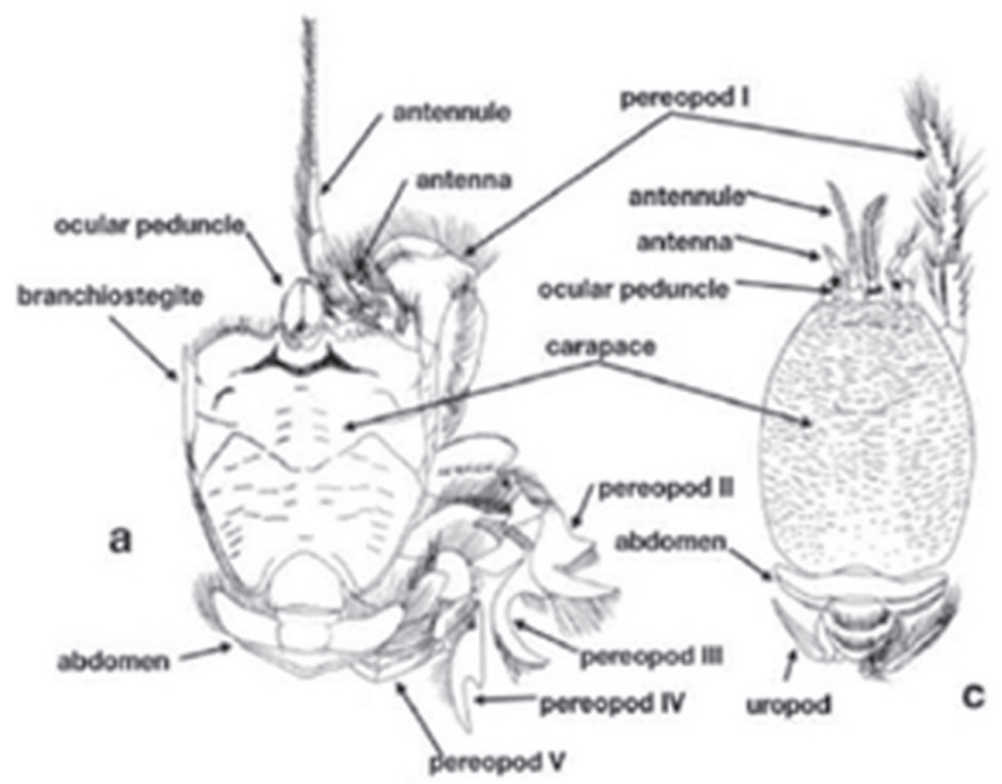

Gambar 2. Hippa sp. (Megawati, 2012) 
Selain dimanfaatkan sebagai sumber protein, undur-undur laut juga dimanfaatkan sebagai indikator pencemaran untuk merkuri, karena dapat mengakumulasi logam tersebut. Undurundur laut mempunyai daerah sebaran yang luas, sangat mudah ditangkap dan dekat dengan aktivitas manusia di pantai (Boere et al., 2011). Menurut Bhagawati et al. (2016), keberadaan undur-undur laut saat ini di alam mulai sulit diperoleh, hal ini disebabkan adanya eksploitasi yang dilakukan secara terus menerus serta terganggunya habitat karena bencana alam maupun dampak kegiatan antropogenik dari masyarakat sekitarnya. Adapun tujuan dari penulisan ini untuk memberikan informasi mengenai undur-undur laut yang belum banyak diketahui oleh masyarakat awam dan peranannya bagi kehidupan manusia.

\section{APA YANG DIMAKSUD DENGAN UNDUR-UNDUR LAUT?}

Di alam diketahui ada dua jenis undur-undur yaitu: "undur-undur laut" dan "undur-undur darat". Keduanya termasuk dalam filum Arthropoda yaitu filum terbesar dalam dunia hewan yang mencakup serangga, laba-laba, udang, lipan, dan lainnya serta dikenal sebagai hewan yang berbuku-buku atau hewan beruas-ruas. Hewan ini hidup di dalam tanah atau pasir laut di pantai yang kering, dan larvanya berjalan mundur saat menggali sarang di tanah atau di pasir, sehingga dinamakan "undur-undur".

Reproduksi dari kedua hewan ini juga berbeda, dimana undur-undur darat mengalami fase sempurna yaitu: mengalami metamorfosis secara lengkap: telur, larva, kepompong, dan dewasa, sedangkan undur-undur laut melalui molting, kopulasi, bertelur dan dewasa layaknya jenis krustasea lainnya (Bhagawati et al., 2016).

\section{TINGKAH LAKU UNDUR-UNDUR \\ LAUT}

Undur-undur laut makan pada saat laut dalam kondisi tenang. Makanan undur-undur laut berupa plankton dan detritus yang terbawa oleh air laut, sehingga sering disebut filter feeder. Undurundur laut memiliki sifat membenamkan diri dalam pasir untuk menghindari predator dan untuk menyimpan energi. Hewan tersebut akan menggali pasir menggunakan uropod dan keempat pasang kakinya, sehingga seringkali muncul ketika tersapu gelombang pasang, dan akan membenamkan diri ketika gelombang surut dan hanya antena saja yang terlihat. Antena berfungsi sebagai penyaring plankton dan detritus-detritus yang terbawa gelombang pasang surut (Megawati, 2012).

\section{PERBEDAAN UNDUR-UNDUR LAUT DAN UNDUR-UNDUR DARAT}

Undur-undur laut, ketam pasir, ketam laut atau juga yutuk, adalah sebangsa krustasea mirip ketam yang tergolong dalam famili Hippidae. Tubuh beruas-ruas hidup di pasir pantai pada garis air laut dalam bahasa Inggris dikenal sebagai "sand crab, mole crab, atau sand flea". Dalam bahasa lokal disebut "yutuk jambe" atau "yutuk batok". Sedangkan 
Undur-undur darat adalah sebangsa wilayah bersuhu hangat dan berpasir. serangga dari famili Myrmeleontidae. Di Untuk lebih jelas melihat perbedaan antara dunia ini diperkirakan ada sekitar 2.000 kedua hewan tersebut dapat dilihat dalam spesies undur-undur darat dan mereka Tabel 1. tersebar di seluruh dunia, terutama di 


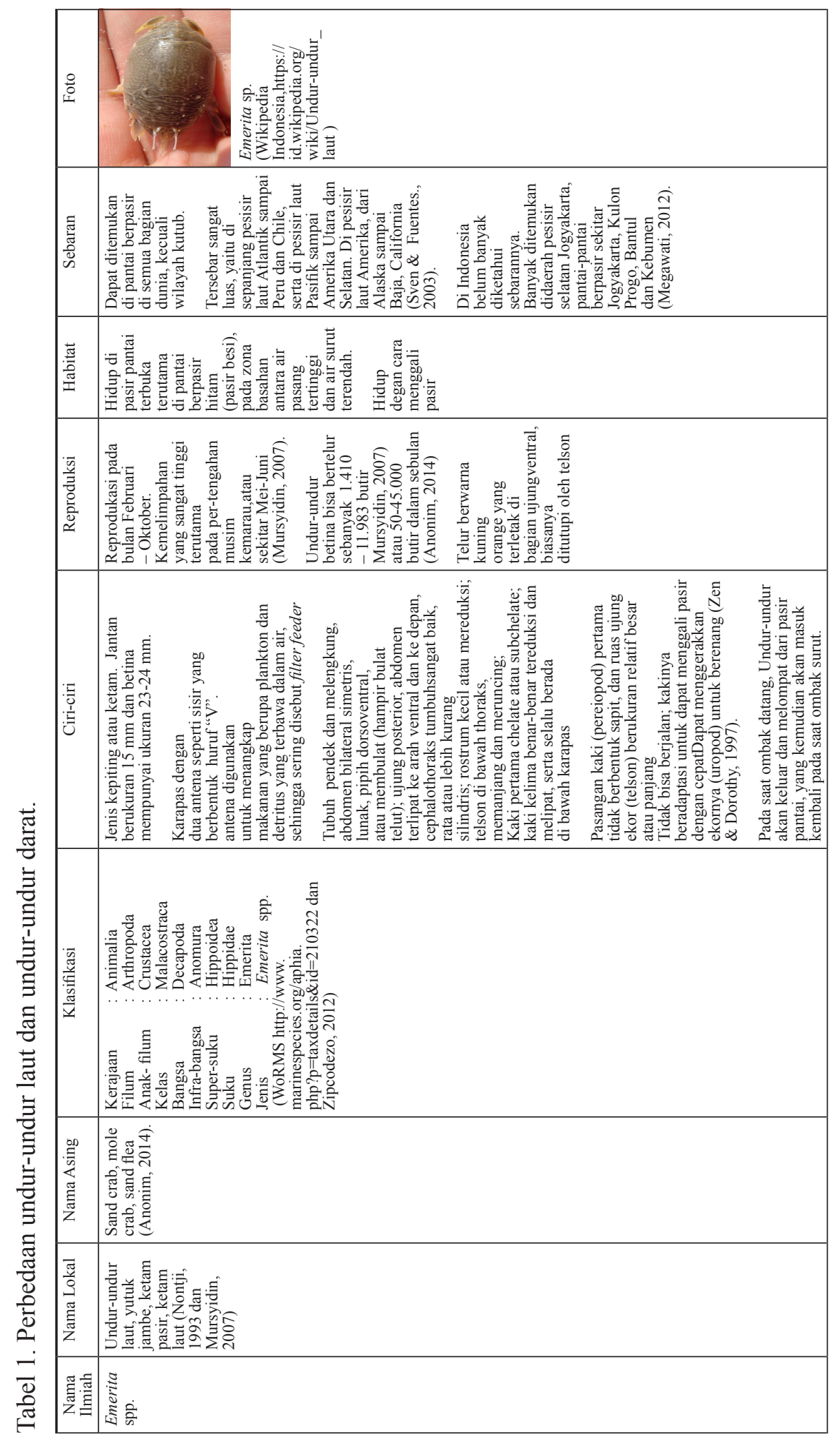




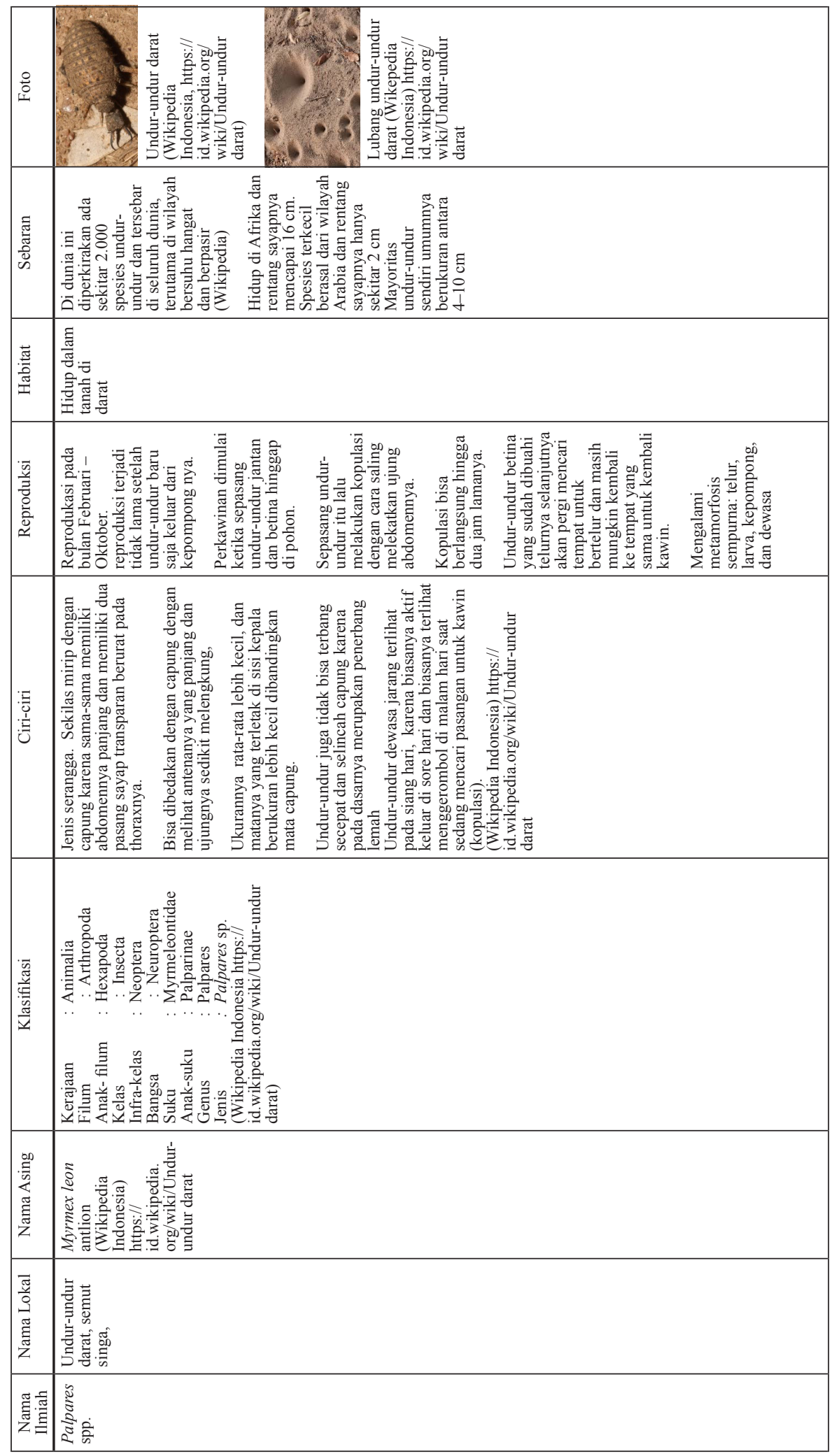




$$
\text { F }
$$




\section{Siklus hidup dan reproduksi undur- undur laut}

Pada umumnya, siklus hidup undur-undur laut yaitu: telur-protozoazoea-megalopa-juvenil-dewasa. Menurut Hanson dalam Megawati (2012), menyatakan bahwa undur-undur laut memiliki daur hidup yang relatif lama. Daur hidup tersebut dapat dilihat pada Gambar 3.

Undur-undur laut memiliki 8-11 stadia larva dan selama stadia tersebut larva berada di lepas pantai (off shore). Ketika stadia larva selesai, hewan tersebut kembali ke pantai memasuki fase recruitment, yang terjadi sepanjang tahun di daerah sub-tropis. Jumlah terbesar terjadi saat musim panas dan musim gugur, saat musim dingin undurundur laut berada dalam pasir di daerah lepas pantai (off shore) dan akan kembali ke pantai saat musim semi. Sedangkan di daerah tropis fase recruitment terjadi pada bulan Februari dan Maret (Phasuk \& Bonruang dalam Megawati, 2012).
Kisaran parameter lingkungan yang memengaruhi kehidupan larva undurundur laut yaitu: suhu $25,5^{\circ} \mathrm{C}$ dan salinitas berkisar 34,45\%o - 35,8 \%o. Musim reproduksi terjadi pada bulan Februari sampai Oktober, biasanya undur undur laut betina mampu menghasilkan telur hingga 50-45.000 butir telur persiklus dan terjadi saat air tenang (FMSA dalam Megawati, 2012).

Hanson dalam Megawati (2012) mengatakan bahwa telur undur-undur laut mempunyai ciri dan warna bermacammacam. Hewan tersebut akan bertelur saat panjang karapas telah mencapai ukuran $11,5 \mathrm{~mm}$ dan telur berwarna kuning. Pada stadia selanjutnya warna telur akan menjadi transparan yang kemudian akan berkembang menjadi embrio. Perkembangan embrio terjadi selama 15-21 hari. Bakir et al. dalam Megawati (2012), membagi stadia telur menjadi tiga stadia yang dapat dilihat pada Gambar 4.

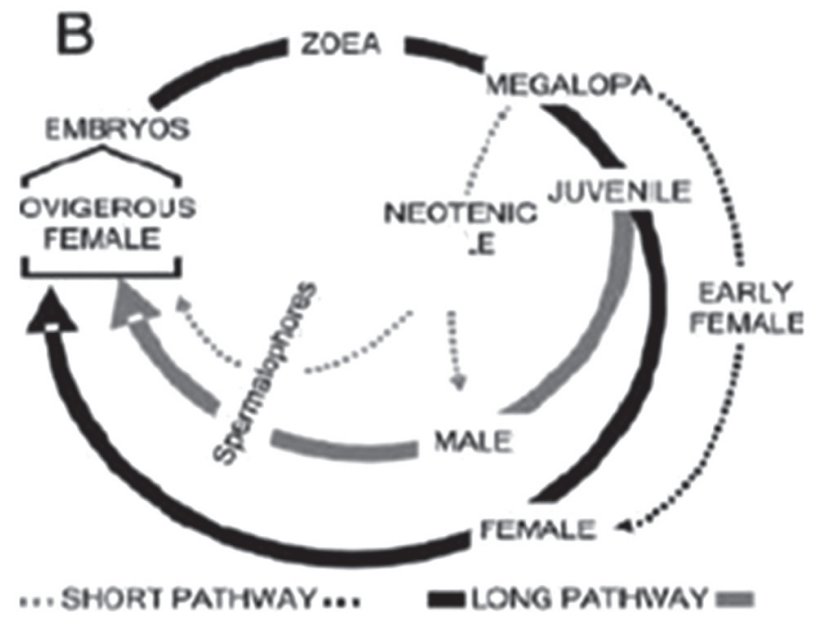

Gambar 3. Daur hidup undur undur laut (Hanson dalam Megawati, 2012) 


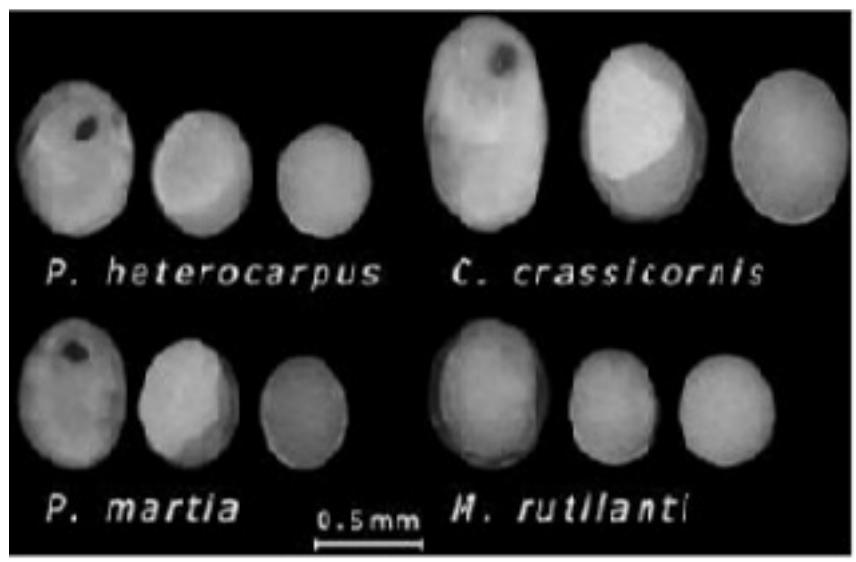

Gambar 4. Stadia telur Ordo Decapoda (Bakir et al. dalam Megawati, 2012)

\section{MANFAAT BAGI KEHIDUPAN}

\section{Sebagai sumber ekonomi keluarga}

Secara ekonomi, undur-undur laut dapat dijadikan sebagai sumber pendapatan (mata pencaharian) keluarga yang sangat menjanjikan dan dapat menambah pendapatan keluarga, karena hewan tersebut memiliki nilai jual. Warga sekitar pesisir pantai menjadikan undurundur laut sebagai makanan khas pantai yang sangat digemari, oleh karenanya setiap hari undur-undur laut sangat dicari atau diburu untuk ditangkap sebagai kebutuhan warung-warung sepanjang pantai. Undur-undur laut atau yutuk dapat dijual dengan harga Rp. 25.000/ kg. Undur-undur laut dapat dikelola sebagai makanan ringan sebagai kudapan (cemilan) seperti: digoreng kering dan dimasukan dalam kemasan plastik yang sangat bagus, dibuat rempeyek, bahkan ditumis sebagai lauk yang dimakan dengan nasi saat hangat (Gambar 5).

Alat tangkap atau pencari undur-undur laut yang dilakukan oleh nelayan biasanya sangat sederhana (alat tradisional setempat), dimana alat itu terbuat dari bambu yang berbentuk seperti huruf T (disebut "sorok"). Pengambilan undur-undur laut dengan cara menyusur pantai sepanjang 3 kilometer atau lebih dengan alat tersebut yang didorong seperti cara pengoperasian alat garuk untuk menjemur padi (Gambar 6). 

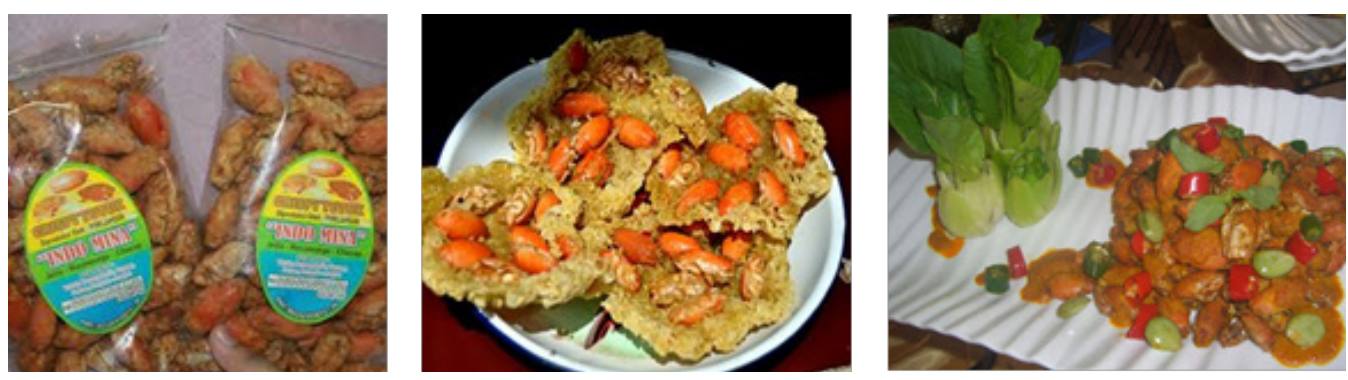

Gambar 5. Macam-macam makanan dari undur-undur laut: a. goreng kering undurundur (dalam kemasan); b. rempeyek undur-undur; C. tumis undur-undur (Wikipedia Indonesia,https://id.wikipedia.org/wiki/Undur-undur_laut).

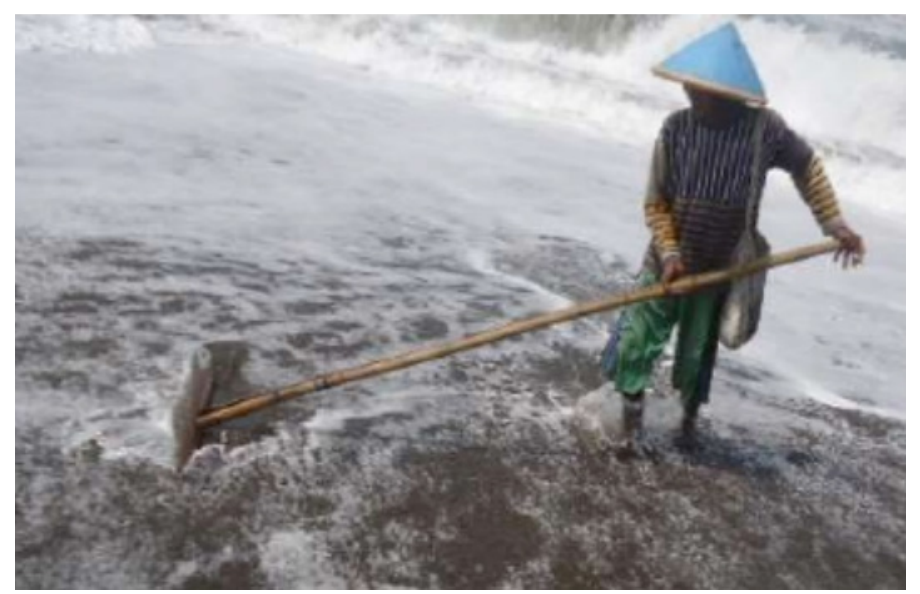

Gambar 6. Alat tangkap untuk mencari undur-undur laut (Megawati, 2012).

Secara ekologis, undur-undur laut merupakan sumberdaya penting dalam siklus rantai makanan yang berperan sebagai konsumen tingkat awal dalam trofik level (Lercari \& Defeo dalam Megawati, 2012). Apabila setiap hari undur-undur laut tersebut ditangkap secara intensif tanpa mempertimbangkan fase-fase penting dalam siklus hidupnya, maka dapat mengganggu fungsi ekologis dan kelestariannya.

Hewan ini sering diburu karena kebutuhan dan pemanfaatan yang meningkat serta tidak diimbangi dengan pengetahuan tentang pelestarian sumberdaya hewan tersebut, sehingga mengganggu kehidupannya di alam. Apabila kondisi tersebut tidak dapat dikendalikan, maka akan memberikan tekanan yang semakin tinggi pada populasi dan habitat undur-undur laut.

\section{Sebagai sumber protein}

Undur-undur laut (Emerita spp.) telah diteliti mempunyai kandungan gizi yang cukup tinggi berupa asam lemak sebesar 3,57\% (dalam $100 \mathrm{mg}$ ) dan protein kasar 32,42\% (dalam $100 \mathrm{mg}$ ). Undurundur laut juga mengandung asam lemak 
omega-3 sebesar $12,49 \%$ (dalam $100 \mathrm{mg}$ ) (Anonim dalam Lisarni et al., 2015). Sedangkan hasil penelitian dari Mursyidin dalam Lisarni et al. (2015), menunjukkan bahwa undur-undur laut mengandung lemak total yang cukup tinggi pula, yaitu berkisar 17,22 - 21,56\%; asam lemak omega-3 total (EPA dan DHA) berkisar: $7,75-14,48 \%$ dibandingkan dengan beberapa jenis crustacea lainnya (udang, lobster dan kepiting). Kandungan EPA (6,41-8,43\%) lebih tinggi dibandingkan kandungan DHA (1,34-6,57\%). Akan tetapi berdasarkan hasil penelitian Puspita dalam Lisarni et al., (2015), pemberian ransum pada undur-undur laut, dapat meningkatkan kandungan omega-3 dalam produksi telur itik. Kadar omega-3 dalam telur itik dengan ransum undur-undur laut $25 \%$ adalah $4,3633 \pm$ $0,0707 \mathrm{mg} / \mathrm{g}$. Kadar omega-3 dalam telur itik dengan ransum 50\% adalah 5,9694 \pm $0,3254 \mathrm{mg} / \mathrm{g}$, dan kadar omega-3 dalam telur itik dengan ransum undur-undur laut $75 \%$ adalah $8,7969 \pm 0,3451 \mathrm{mg} / \mathrm{g}$.

\section{Sebagai umpan pancing dan cara mendapatkannya}

Undur-undur laut sudah sejak lama menjadi umpan yang cukup baik untuk memancing ikan di laut karena selain awet, undur-undur laut juga sangat disukai oleh ikan. Permasalahan yang ada adalah tidak mudah menemukan atau mencari umpan yang satu ini.

Undur-undur laut adalah hewan yang biasa hidup membenamkan diri di pasir di pinggir-pinggir pantai. Langkahlangkah yang bisa dilakukan agar mendapatkan undur-undur laut dengan mudah yaitu: 1. lakukan pengamatan saat ombak datang dan pergi, setelah ombak pergi akan terlihat gerakan di antara pasir-pasir atau gundukan pasir kecil mirip dengan batu-batu hitam, 2 . lakukan penangkapan segera saat ombak kedua atau ketiga datang, 3. perhatikan tempat awal dimana terlihat pergerakanpegerakan tadi, biasanya undur-undur laut akan berada tak jauh dari tempat semula pengamatan.

Cara lain yang juga mudah dilakukan adalah memburu dengan cara memancing. Umpan yang digunakan adalah potongan udang laut. Cara ini adalah cara yang cukup efektif karena sangat mudah dilakukan, yakni: 1 . siapkan senar yang cukup panjang dan ikatkan potongan udang atau jenis umpan lain yang berbau amis untuk mengundang undur-undur laut, 2. lemparkan umpan pada tepi pantai yang berbatasan langsung dengan ombak, 3 . berikan pemberat pada ujung senar untuk menghindari umpan terbawa arus ombak, 4. amati dari kejauhan dan akan terlihat undur-undur laut datang bersamaan dengan datang dan perginya ombak pantai, 5. segera buru disekitar umpan yang dilempar tadi.

Salah satu ciri yang jelas bahwa terdapat undur-undur laut adalah saat umpan terbenam di pasir pantai. Undurundur laut untuk umpan pancing banyak terdapat di pantai-pantai yang berpasir. Di Jogyakarta undur-undur laut ini bisa didapatkan di pantai Parangtritis, pantai Parangkusumo, pantai Trisik, pantai Glagah, pantai Kwaru, pantai Congot dan masih banyak lagi pantai-pantai sepanjang Jogyakarta. 


\section{PENUTUP}

Penangkapan atau perburuan undur-undur laut untuk kepentingan komersial sebaiknya diikuti dengan pengetahuan mengenai pengelolaan perikanan berkelanjutan yang dianjurkan yaitu perikanan berbasis masyarakat. Aktifitas penangkapan yang bersifat komersial, tidak dilarang, tetapi dianjurkan agar penangkapannya tidak melebihi daya dukung perairan tersebut. Tidak melakukan perburuan atau penangkapan saat undur-undur laut atau kepiting pasir sedang bertelur (pada bulan Maret).

Disarankan untuk melakukan pembudidayaan undur-undur laut atau kepiting pasir, sehingga keberadaannya tetap lestari di alam. Seleksi penangkapan juga sangat disarankan dengan cara memperhatikan ukuran yang boleh diambil dan mengembalikan betina bertelur ke alam.

\section{DAFTAR PUSTAKA}

Anonim. 2014. Fishing Destin Guide. Guide to fishing around Destin and the Florida Panhandle. Sand Fleas (Mole Crabs or Sand Crabs). Prime surf fishing bait. FishingDestinGuide@cox.net. (Diakses, 7 Desember 2017).

Anonim. 2017. Catalog. http:// catalog.digitalarchives. $\mathrm{tw} / \mathrm{item} / 00 / 04 / 7 \mathrm{e} / 7 \mathrm{a}$. html digitalarchives.tw/ item/00/04/7e/7a.html (Diakses
15 Desember 2017).

Bhagawati, D., S. Anggoro, M. Zainuri, dan L. Sya'rani. 2016. Kontribusi taksonomi dalam pendayagunaan spesies: kajian atribut morfologi dan kunci dikotomi kepiting Yutuk (Crustacea: Hippoidea) dari pesisir Cilacap. Prosiding Seminar Nasional Tahunan ke V Hasil-hasil Penelitian Perikanan dan Kelautan. 550564.

Boere, V., E. R. Cansi, A. B. B. Alvarenga and I. O. Silva. 2011. The burying behaviour of the mole crab before and after an accident with urban sewage effluents in Bombinhas Beach, Santa Catarina, Brazil. AmbiAqua, Taubate, 6 (3): 70-76.

Hartono, E., E. S. Rejeki dan A. A, Puspitasari, 2010. Pengaruh asupan makanan undur-undur laut terhadap kandungan omega-3 pada telur itik. Fakultas farmasi Universitas Setia Budi, Surakarta.

Lisarni, A. D., E. S. Rejeki dan Suhartinah., 2015. Penetapan kadar omega-3 Undur-undur laut (Emerita emeritus) dalam bentuk granul, bubur dan mentah secara kromatografi gas. Jurnal Farmasi Indonesia, 12 (3): 15-22.

Megawati, E. 2012. Studi beberapa aspek biologi kepiting Pasir 
di Kecamatan Buluspesantren kabupaten Kebumen. Skripsi. Departemen Manajemen Sumberdaya Perairan, Fakulatas Perikanan Dan Ilmu Kelautan. Institut Pertanian Bogor. 41 hal.

Mashar, A. dan Y. Wardiatno, $2013 \mathrm{a}$. Aspek pertumbuhan undurundur laut Hippa adactyla dari pantai berpasir kabupaten Kebumen. Jurnal Biologi Tropis, 13 (1): 119-127.

Mashar, A. dan Y. Wardiatno, 2013b. Aspek undur-undur laut Emerita emeritus dari pantai berpasir kabupaten Kebumen. Jurnal Biologi Tropis, 14 (1): 29-38.

Mursyidin, D. H., 2007. Kandungan asam lemak omega 6 pada ketam pasir (mole crab) di pantai Selatan Yogyakarta. Bioscientiae, 4 (2): 79-84.

Nontji, A. 1987. Laut Nusantara. Djambatan, Jakarta, 196 hal.

Puspita, A. A. 2009. Pengaruh asupan makanan Undur-undur laut terhadap kandungan omega-3 pada telur Itik. Skripsi. Fakultas Farmasi, Universitas Setia Budi, Surakarta.
Sven, T. and V. Fuentes. 2003. First record of anomuran and brachyuran larvae (Crustacea: Decapoda) from Antarctic waters. Polar Biology, 26: 279-282.

Zen, F. and H. P. Dorothy, 1997. Digging in sand crabs (Decapoda, Anomura, Hippoidea): interleg coordination". Journal of Experimental Biology 200 (4): 793-805.

Zipcodezoo. 2012. Classification of Emerita emeritus. http://www. zipcodezoo.com/classificationof-Emerita (Diakses 15 Desember, 2017).

WikipediaIndonesia:https://id.wikipedia. org/wiki/Undur-undur laut (Diakses, 3 Desember 2017).

WikipediaIndonesia:https://id.wikipedia. org/wiki/Undur-undur darat (Diakses, 5 Desember, 2017).

World Register of Marine Species (WoRMS): http://www. marinespecies.org/aphia. php? $\mathrm{p}=$ taxdetails \&id $=210322$ (Diakses, 7 Desember, 2017). 